\title{
ISOLATION, PRODUCTION AND OPTIMIZATION OF CELLULASE BY BACILLUS PUMILUS UNDER SUBMERGED FERMENTATION USING LABORATORY MEDIUM BY SMF METHOD
}

\author{
Ms. Hiral Shah \\ Ms. Ankita Patel \\ Ms. Rinku Valand \\ Ms. Payal Rathod \\ Ms. Nidhi Gondaliya
}

\begin{abstract}
:
Cellulolytic waste is superfluous in lithosphere and its conversion is one of the basic necessities. In current research, we have screen out potential bacterial isolates that were found capable for degradation of cellulose material. They can easily convert it into simple usable form of sugar. All isolates were capable to use cellulose in natural environmental condition such as $\mathrm{pH}$, humidity and moderate temperature range. Isolation was done using to carboxymethycellulose agar medium. While, the isolates were cultivated by submerged fermentation method (Smf). Among all isolates Bacullis pumilus was found most potent strain for cellulose degradation and for production of cellulase at large scale.
\end{abstract}

\section{Key words}

Cellulolytic waste, Bacillus pumilus, carboxymethycellulose agar, Submerged Fermentation Method (Smf)

\section{Introduction}

Enzyme are delicate protein molecules necessary for life. Lignocellulosic biomass accounts for $50 \%$ of all the biomass available in world (singhania et al.,2010). Lignocellulosic biomass is mainly composed of plant cell walls, the structural carbohydrates cellulose and hemicellulose andheterogeneous phenolic polymer lignin is the main component (Goyal,2014). Recent times cellulosic waste is accumulated by agricultural, industrial and municipal in enormous form and inefficiently utilized due to high cost. lignocellulosic Waste from agricultural and industrial have great potential to renewable source for regeneration of energy but looking for inexpensive and regenerate in abundance form. (Annamalai et. al., 2014)

Cellulose is commonly degraded by an enzyme called cellulase. This enzyme is produced by several microorganisms commonly by bacteria and fungi (Immanuel et al., 2006). The complete 
Towards Excellence: An Indexed, Refereed \& Peer Reviewed Journal of Higher Education / Ms. Hiral Shah, Ms. Ankita Patel, Ms. Rinku Valand, Ms. Payal Rathod \& Ms. Nidhi Gondaliya / Page

$\underline{717-733}$

enzymatic hydrolysis of cellulosic materials needs different types of cellulase; endoglucanase (1,4- $\beta$-d-glucan-4-glucanohydrolase), exo cellobiohydrolase (1,4- $\beta$-d-glucan glucohydrolase) and $\beta$-glucoside glucohydrolase. (Azadian et. al., 2017)Cellulases are observed as the most important renewable resource for bioconversion. It has been become the economic interest to develop an effective method to hydrolyze the cellulosic biomass (Chander Kuhad et. al.,2016).

Cellulase is an important and essential enzyme to depolymerize cellulose into fermentable sugar and utilized for renewable sources (Goa et. al., 2012). Compared with fungi,bacteria have a high growth rate and good potential for cellulose production. Some bacterial species, viz Cellulomonas Species, Pseudomonas Species, Bacillus Species and Micrococcus have cellulolytic property (Abou-Taleb et. al., 2009)

Cellulases have attracted much interest because of the diversity of their application. The major industrial applications of cellulases are in textile industry for bio-polishing of fabrics as well as in house hold laundry detergents for improving fabric softness and brightness. Application of enzyme in textile, food, detergent, leather and paper industries demands identification of highly stable enzyme active at extreme $\mathrm{pH}$ and Temperature. Cellulase is used in the fermentation of bio mass into into biofuels, fibre modification and they are even used for pharmaceutical applications (Sadhu et.al., 2013)

The purpose of this present study is to screen out potential cellulase producing bacteria and extensively discover its degradation capacity of cellulose and hemicelluloses containing waste materials.

\section{[2] MATERIAL AND METHOD}

\subsection{Primary screening for cellulase producing bacteria}

78 different soil samples were collected from industrial and agricultural zones for primary screening of cellulase producing bacterial species. The collected soil sample were suspended and $1 \mathrm{gm}$ of sample was serially diluted in $10 \mathrm{ml}$ of sterile distilled water and mixed properly upto $10^{-7}$.while from each tube $100 \mu \mathrm{l}$ of sample was spread on agar plates. The medium for isolation contains $1.0 \mathrm{gm}$ peptone, $0.3 \mathrm{gm}$ meat extract, $0.5 \mathrm{gm} \mathrm{Nacl}, 3.0 \mathrm{gm}$ agar powder, 100 $\mathrm{ml}$ distilled water.. The plates were incubated for 24 hours at $37^{\circ} \mathrm{C}$ whereas $\mathrm{pH}$ was maintain 7.4

\section{$\underline{\text { 2.2 Secondary screening for cellulase producing bacterial }}$}

The isolated colonies were transferred on to carboxymethycellulose agar plates. The CMC agar plate contain 3.0 gm carboxymethylcellulose, 1.0 gm peptone, 0.3 gm meat extract, $0.5 \mathrm{Nacl}, 3.0$ gm agar powder, $100 \mathrm{ml}$ distilled water. The plates were inoculated at $37{ }^{\circ} \mathrm{C}$ for 48 hours. The 
Towards Excellence: An Indexed, Refereed \& Peer Reviewed Journal of Higher Education / Ms. Hiral Shah, Ms. Ankita Patel, Ms. Rinku Valand, Ms. Payal Rathod \& Ms. Nidhi Gondaliya / Page

$\underline{717-733}$

incubated CMC agar plates were flooded with $1 \%$ Congo red and allow to stand for $15 \mathrm{~min}$ at room temperature. $1 \mathrm{M} \mathrm{Nacl}$ was thoroughly used for counterstaining the plates. Clear zones were appeared around growing bacterial colonies indicating cellulose hydrolysis. The bacterial colonies having clear zone were selected for identification and cellulose production. Further bacterial straining was purified by repeated streaking. The purified colonies were preserved at $4^{\circ} \mathrm{C}$.(Shaikh et. at., 2013)

\section{$\underline{\text { 2.3 Production of cellulase }}$}

\subsubsection{Development of inoculums}

The selected bacterial cultures were individually maintained on $\mathrm{CMC}$ agar slant at $4^{\circ} \mathrm{C}$. The selected bacterial culture was inoculated in broth medium containing $1.0 \mathrm{gm}$ peptone, $0.3 \mathrm{gm}$ meat extract, $0.5 \mathrm{gm} \mathrm{Nacl}$ and $100 \mathrm{ml}$ distilled water. After the incubation period these bacterial cells were used as inoculum.

\subsubsection{Cellulase enzyme (crude form) production by submerged fermentation process.}

The selected bacterial isolates were studied for cellulase enzyme production in submerged fermentation process. Tack $250 \mathrm{ml}$ Erlenmeyer flask containing $50 \mathrm{ml}$ production medium. The product on medium containing 3.0 gm Carboxymethylcellulose, $1.0 \mathrm{gm}$ peptone, $0.3 \mathrm{gm}$ meat extract, $0.5 \mathrm{gm} \mathrm{Nacl}, 100 \mathrm{ml}$ distilled water and autoclaved at $121{ }^{\circ} \mathrm{C}$ for $15 \mathrm{~min}$. After autoclave, the medium was inoculated with $3.0 \mathrm{ml}$ of bacterial isolates and inoculated in a rotary shaker at $37 \pm 2{ }^{\circ} \mathrm{C}$ for 48 hours of fermentation period with agitation speed of $100 \mathrm{rpm}$. The enzyme activity checked at an interval of 24 hours. After centrifugation served as crude enzyme source.

\subsubsection{Estimation of cellulase enzyme}

Estimation of cellulase enzyme activity was assayed using dinitrosalisic acid (DNSA) reagent (Miller, 1959) by estimation of reducing sugars released from CMC. Crude enzyme was added to $2.0 \mathrm{ml}$ of $1 \% \mathrm{CMC}$ solution to the tube as substrate. Incubate the tube at $55{ }^{\circ} \mathrm{C}$ for $30 \mathrm{~min}$. now add $1 \mathrm{ml}$ DNSA solution to stop the enzyme activity. Then keep it in boiling water bath for $15 \mathrm{~min}$. add $6 \mathrm{ml}$ distilled water and measured O.D at $540 \mathrm{~nm}$ absorbance. Cellulase production was estimated by using glucose calibration curve. One unit (U) of enzyme activity is expressed as the quantity of enzyme, which is required to release $1 \mu \mathrm{mol}$ of glucose per minute under stander assay condition (Yang et al.,2014).

\subsection{Identification for cellulase producing bacteria}

The bacterial isolates were presumptively identified by means of morphological examination and some biochemical characterizations. 
Towards Excellence: An Indexed, Refereed \& Peer Reviewed Journal of Higher Education / Ms. Hiral Shah, Ms. Ankita Patel, Ms. Rinku Valand, Ms. Payal Rathod \& Ms. Nidhi Gondaliya / Page

$\underline{717-733}$

\subsection{Morphological and Biochemical characterization examination staining techniques}

All isolates were stained using different staining techniques for morphological studies such as Gram staining, nucleus staining and endospore staining. While, biochemical studies included indole test, methyl-red test, vogues proskauer test, citrate utilization test, catalase test, oxidase test, gelatin test, casein hydrolysis test, congo red test, motility test, amylase test, nitrate reduction test, carbohydrate fermentation test by standards method. The various media was prepared as per standard protocol in sterile distilled water and $\mathrm{pH}$ was adjusted accordingly.

\subsection{Optimization of culture condition on cellulase activity}

\section{a) Effect of $\mathrm{pH}$, Temperature, incubation period, carbon and nitrogen source on cellulase production}

In order to determine all effect on cellulase production, the selected bacterial isolate was grown in $\mathrm{CMC}$ broth and incubated at various parameters. The influence of all factors on enzyme activity was determined by measuring cellulase activity at varying $\mathrm{pH}$ values from 4 to 8 and Temperature varying from 28 to $45^{\circ} \mathrm{C}$ and incubation period varying from 24 to $120 \mathrm{~h}$ at $37{ }^{\circ} \mathrm{C}$. both carbon and nitrogen sources have wide variety of impacts on the various organisms and enzyme production. Carbon and nitrogen sources have been replaced with various substances. Carbone source such as glucose, xylose, lactose, maltose, sucrose and nitrogen source such as sodium nitrate, urea, beef extract, yeast extract, ammonium phosphate. All factor influence on enzyme activity was determined by measuring cellulase activity. 
Towards Excellence: An Indexed, Refereed \& Peer Reviewed Journal of Higher Education / Ms. Hiral Shah, Ms. Ankita Patel, Ms. Rinku Valand, Ms. Payal Rathod \& Ms. Nidhi Gondaliya / Page $\underline{717-733}$

\subsection{RESULT AND DISCUSSION}

\subsection{SAMPLE COLLECTION}

A total of 78 samples were collected from composting sites, paper and pulp industries, different farms as well as decaying wood, garden soil sample were also collected in ziplock bag. As shown in Fig 3.1

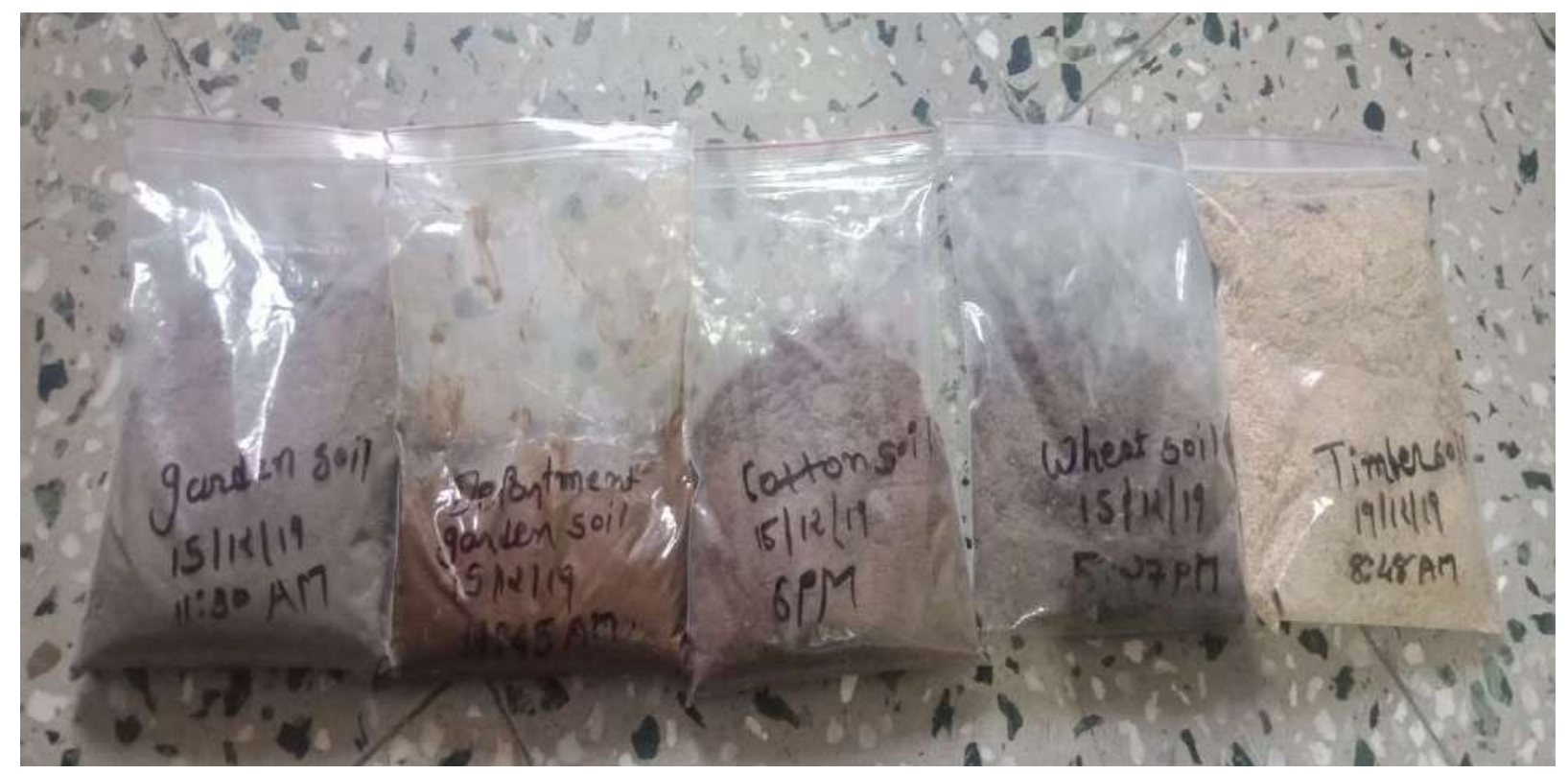

Fig 3.1 Image of collected soil sample

\subsection{Primary screening}

Among all isolates 53 bacterial isolates were obtained in pure form with positive results. This isolates were showing cellulase production. All isolates were purified in pure culture form on Nutrient agar

\subsection{Secondary screening}

Seconday screening of cellulase producing bacteria from pure culture was carried out using CMC medium. 17 potent isolates were collected showing zone of hydrolysis surrounding their 
Towards Excellence: An Indexed, Refereed \& Peer Reviewed Journal of Higher Education / Ms. Hiral Shah, Ms. Ankita Patel, Ms. Rinku Valand, Ms. Payal Rathod \& Ms. Nidhi Gondaliya / Page $\underline{717-733}$

colonies. (Figure 3.3). From which highly potential eight isolates were selected for further studies.

Table. 3.1 Potent isolation, source and morphology character.

\begin{tabular}{|l|l|l|}
\hline Isolate & Location & Gram reaction \\
\hline Ps-1 & Timber soil, Geeta mandir, Ahemdabad. & Gram positive \\
\hline Ps-2 & Timber soil, Geeta mandir, Ahemdabad & Gram positive \\
\hline Ps-3 & Timber soil, Geeta mandir, Ahemdabad & Gram negative \\
\hline Ps-4 & Timber soil, Geeta mandir, Ahemdabad & Gram positive \\
\hline ps-6 & Wheat growing soil, Vasna, Kathlal & Gram positive \\
\hline Ps-7 & Timber soil, Geeta mandir, Ahemdabad. & Gram positive \\
\hline Ps-8 & Cotton soil, Vasna, Kathlal & Gram positive \\
\hline
\end{tabular}

\subsection{Study of cultural characteristics of the isolates}

As shown below table 3.4 on the basis of visual observation character were noted and gram staining (table 3.3) was performed to study morphology characters.

Table 3.2: Study of cultural characteristics of isolates

\begin{tabular}{|l|l|l|l|l|l|l|l|}
\hline Isolates & Size & Shape & Margin & Elevation & Texture & Opacity & Pigment \\
\hline Ps-1 & Big & Round & Undulate & Raised & Smooth & Transparent & White \\
\hline Ps-2 & Small & Round & Concentric & Raised & Smooth & opaque & Off white \\
\hline Ps-3 & Big & Irregular & Undulate & convex & Granular & Opaque & White \\
\hline Ps-4 & Big & Irregular & Entire & $\begin{array}{l}\text { Slightly } \\
\text { raised }\end{array}$ & Granular & Opaque & Off white \\
\hline Ps-6 & Medium & Round & Entire & Flat & Smooth & Opaque & White \\
\hline
\end{tabular}


Towards Excellence: An Indexed, Refereed \& Peer Reviewed Journal of Higher Education / Ms. Hiral Shah, Ms. Ankita Patel, Ms. Rinku Valand, Ms. Payal Rathod \& Ms. Nidhi Gondaliya / Page

$\underline{717-733}$

\begin{tabular}{|l|l|l|l|l|l|l|l|}
\hline Ps-7 & Big & Iregular & Undulate & Raised & Rough & Opaque & White \\
\hline Ps-8 & Medium & Irregular & Erose & Flate & Punctuate & Opaque & Off white \\
\hline
\end{tabular}

\subsection{Identification of potent cellulase producing isolate Ps-7}

\subsubsection{Study of Morphology characteristic of isolates Ps-7}

Fig 3.4 image of Gram staininig

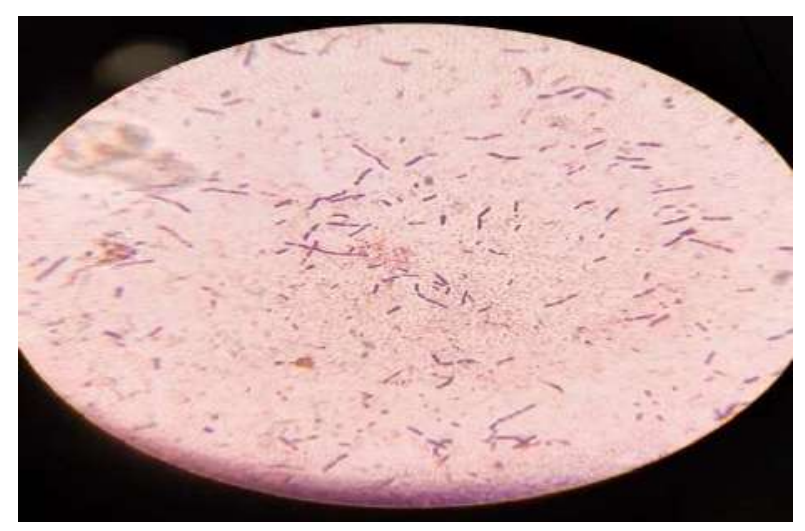

Table 3.3: morphological characterization of selected isolate ps-7

\begin{tabular}{|l|l|}
\hline Gram reaction & Gram positive \\
\hline Shape and Arrangement & Big and rod shape \\
\hline Spore staining & Spore forming \\
\hline Motility test & Positive \\
\hline
\end{tabular}

\subsubsection{Study of biochemical activity of potent isolate Ps-7}

\begin{tabular}{|l|l|}
\hline \multicolumn{2}{|l|}{ Biochemical characteristics of isolate Ps-7 } \\
\hline Biochemical test & Isolate Ps-7 \\
\hline Sugar utilization test & Acid only \\
\hline Catalase test & $+\mathrm{ve}$ \\
\hline Voges-proskauer test (V-P test) & $+\mathrm{ve}$ \\
\hline Indole production test & $+\mathrm{ve}$ \\
\hline Ammonia production test & $+\mathrm{ve}$ \\
\hline Starch hydrolysis & $+\mathrm{ve}$ \\
\hline
\end{tabular}


Towards Excellence: An Indexed, Refereed \& Peer Reviewed Journal of Higher Education / Ms. Hiral Shah, Ms. Ankita Patel, Ms. Rinku Valand, Ms. Payal Rathod \& Ms. Nidhi Gondaliya / Page

$\underline{717-733}$

\begin{tabular}{|l|l|}
\hline Casein hydrolysis & $+\mathrm{ve}$ \\
\hline Nitrate reduction test & $+\mathrm{ve}$ \\
\hline
\end{tabular}

Table 3.4: Biochemical characteristics of Ps-7

3.6. Zone of hydrolysis of isolate Ps-7 and bacterial identification report 
Towards Excellence: An Indexed, Refereed \& Peer Reviewed Journal of Higher Education / Ms. Hiral Shah, Ms. Ankita Patel, Ms. Rinku Valand, Ms. Payal Rathod \& Ms. Nidhi Gondaliya / Page

\section{$\underline{717-733}$}

\section{Fig 3.5 : CMC agar plate}

Image 3.5 is the Bacillus sp. Ps-7 on CMC agar plate showing fine clear zone and maximum hydrolysis the substrate carboxymethaylcellulose compare to remaining seven bacillus culture. So from cultural, microscopic, and biochemical characteristics the culture ps-7 shows good results. Therefore this culture was taken for further identification by VITEK 2 SYSTEMS.

\section{Fig 3.6 bacterial identification report}

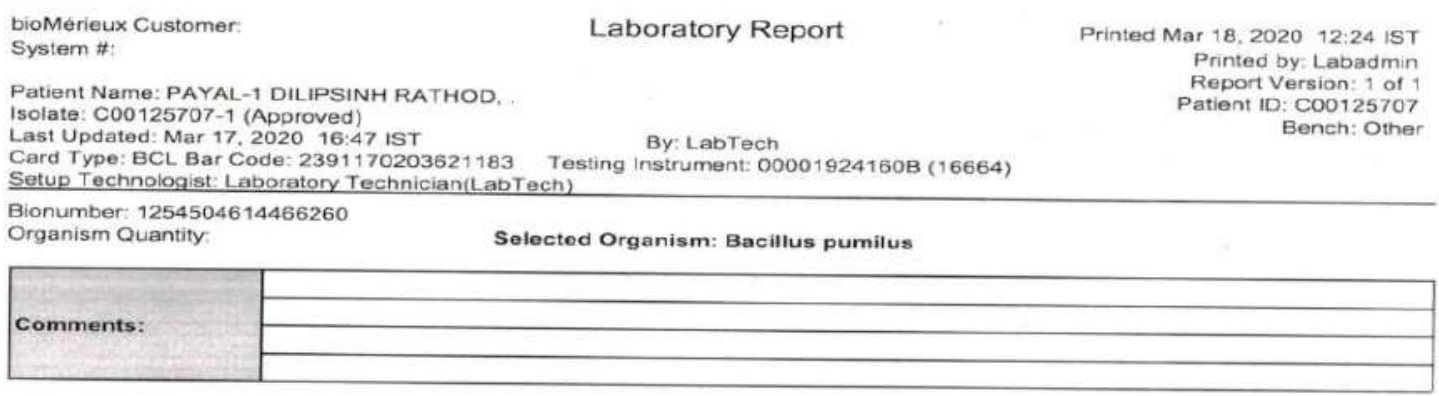

\begin{tabular}{|c|c|c|c|c|c|c|}
\hline \multirow{3}{*}{$\begin{array}{l}\text { Identification } \\
\text { Information }\end{array}$} & \multicolumn{5}{|c|}{ McFarland: $1.86 \quad(1.80-2.20)$} & \multirow[b]{2}{*}{$\begin{array}{l}\text { Feb } 8,202112: 00 \\
\text { IST }\end{array}$} \\
\hline & Card: & $\mathrm{BCL}$ & $\begin{array}{l}\text { Lot } \\
\text { Number: }\end{array}$ & 2391170203 & Expires: & \\
\hline & Completed: & $\begin{array}{l}\text { Mar } 18,2020 \\
06: 36 \text { isT }\end{array}$ & Status: & Final & $\begin{array}{l}\text { Analysis } \\
\text { Time: }\end{array}$ & 13.83 hours \\
\hline Organism Origin & \multicolumn{6}{|l|}{ VITEK 2} \\
\hline \multirow{2}{*}{ Selected Organism } & \multicolumn{2}{|l|}{$89 \%$ Probability } & \multirow{2}{*}{\multicolumn{2}{|c|}{ Bacillus pumilus }} & & \\
\hline & Bionumber: 1 & 1254504614466260 & & & Confidence: & Good identification \\
\hline \multicolumn{7}{|c|}{\begin{tabular}{|l|l|} 
SRF & \\
Organism & \\
\end{tabular}} \\
\hline \multicolumn{7}{|c|}{ Analysis Organisms and Tests to Separate: } \\
\hline \multicolumn{7}{|l|}{ Analysis Messages: } \\
\hline \multicolumn{7}{|c|}{$\begin{array}{l}\text { Contraindicating Typical Biopattern(s) } \\
\begin{array}{ll}\text { Bacillus pumilus } & \text { LeuA(79),APPA(17),ELLM(88),TyrA(99), dGAL(12). }\end{array}\end{array}$} \\
\hline
\end{tabular}

\begin{tabular}{|c|c|c|c|c|c|c|c|c|c|c|c|c|c|c|c|c|c|}
\hline \multicolumn{18}{|c|}{ Biochemical Details } \\
\hline 1 & BXYL & + & 3 & LysA & - & 4 & Aspa & - & 5 & LeuA & . & 7 & PheA & + & 8 & ProA & - \\
\hline 9 & BGAL & + & 10 & PyrA & - & 11 & $A G A L$ & + & 12 & AlaA & - & 13 & TyrA & - & 14 & BNAG & + \\
\hline 15 & APPA & + & 18 & CDEX & - & 19 & dGAL & + & 21 & GLYG & - & 22 & INO & - & 24 & MdG & - \\
\hline 25 & ELLM & - & 26 & $\mathrm{MdX}$ & - & 27 & AMAN & + & 29 & MTE & - & 30 & GIyA & + & 31 & dMAN & + \\
\hline 32 & dMNE & + & 34 & $d M L Z$ & - & 36 & NAG & - & 37 & PLE & - & 39 & IRHA & - & 41 & BGLU & + \\
\hline 43 & BMAN & - & 44 & $\mathrm{PHC}$ & - & 45 & PVATE & + & 46 & AGLU & - & 47 & dTAG & + & 48 & dTRE & + \\
\hline 50 & INU & - & 53 & dGLU & + & 54 & dRIB & + & 56 & PSCNa & - & 58 & $\mathrm{NaCl} 6.5 \%$ & + & 59 & KAN & - \\
\hline 60 & OLD & - & 61 & ESC & + & 62 & TTZ & + & 63 & POLYB_R & - & & & & & & \\
\hline
\end{tabular}


Towards Excellence: An Indexed, Refereed \& Peer Reviewed Journal of Higher Education / Ms. Hiral Shah, Ms. Ankita Patel, Ms. Rinku Valand, Ms. Payal Rathod \& Ms. Nidhi Gondaliya / Page $\underline{717-733}$

3.7. Result for estimation of reducing sugar by DNSA method

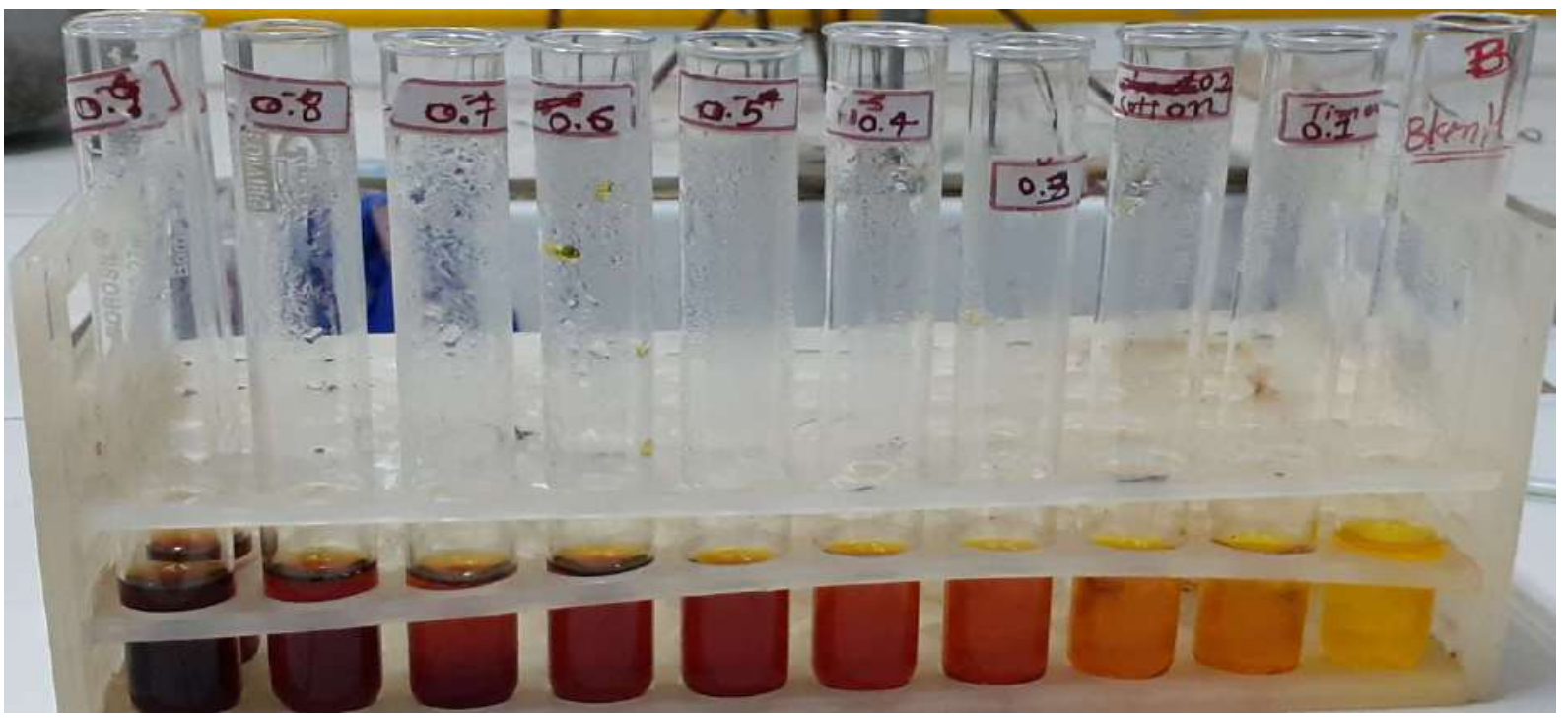

\section{Estimation of Glucose by DNS method}

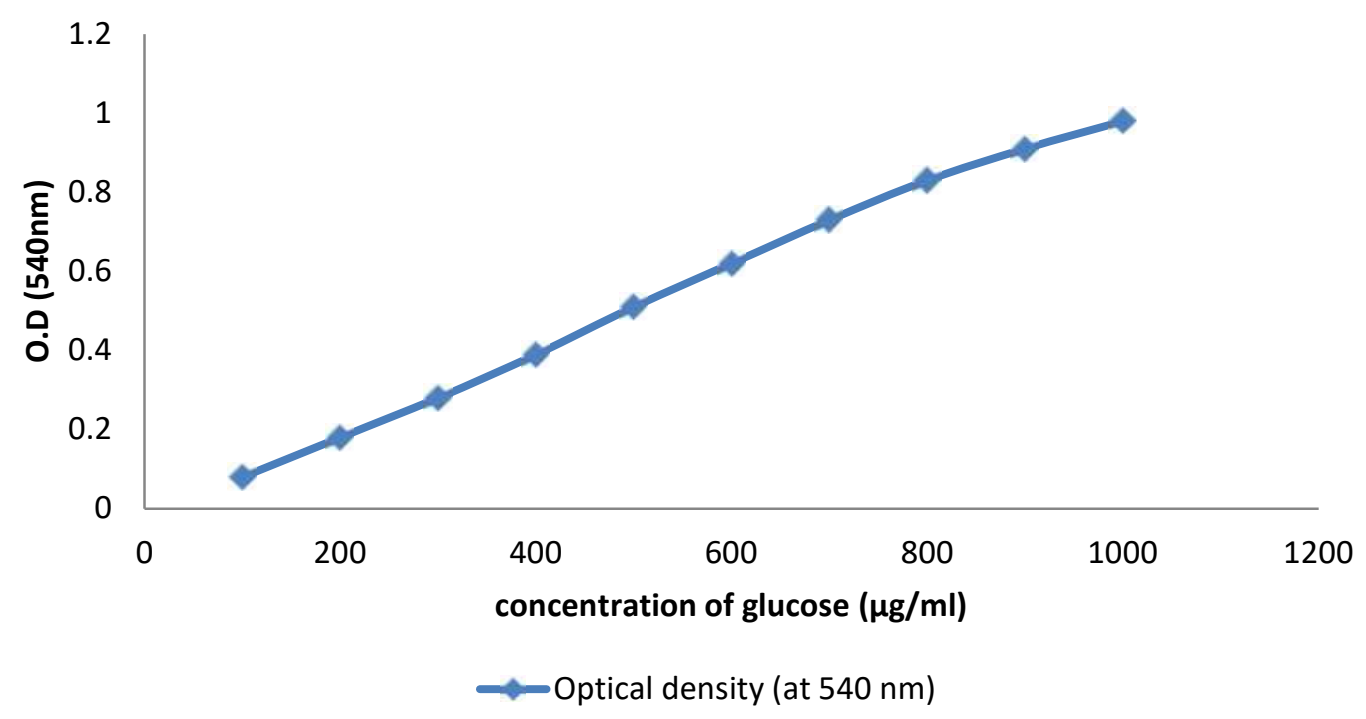

Graph: 3.1: standard graph of glucose by DNS method 
Towards Excellence: An Indexed, Refereed \& Peer Reviewed Journal of Higher Education / Ms. Hiral Shah, Ms. Ankita Patel, Ms. Rinku Valand, Ms. Payal Rathod \& Ms. Nidhi Gondaliya / Page

\section{$\underline{717-733}$}

\subsection{Cellulase production from optimized medium}

Isolation and screening are the rate limiting in search and discovery of previously unknown natural products from microorganisms (Sethi et. al., 2013).

Seven isolates Ps-1, Ps-2, Ps-3, Ps-4, Ps-6, Ps-7 and Ps-8 of cellulolytic bacteria from different soil sample were selected for optimization process for production of maximum cellulase. In this study cellulase production was done by submerged fermentation method (Sonia sethi et al, 2013).

As seen in graph 5.1 endoglucanase activities were in different bacillus spp Ps-1, Ps-2, Ps-3, Ps4, Ps-6, Ps-7, Ps-8 at shaking condition 1.716, 2.004, 2.967, 1.996, 3.418, 3.568, 2.676 $\mathrm{U} / \mathrm{mL} / \mathrm{min}$ for 48 hours at room temperature, respectively. Maximum cellulase activity was observed in Ps-7 for 48 hours, which was $3.568 \mathrm{U} / \mathrm{mL} / \mathrm{min}$.

In the present study Bacillus spp Ps-7 also has been isolated and showed cellulase activity. Similarly kanafusa-shinkai, et. al.,( 2012). also reported the cellulase activity of $0.9 \mathrm{U} / \mathrm{mL}$ and $0.140 \mathrm{U} / \mathrm{mL}$ of certain bacterial and fungal species, respectively, which have high growth rate as compared to fungi, good potential to be used in cellulose production.

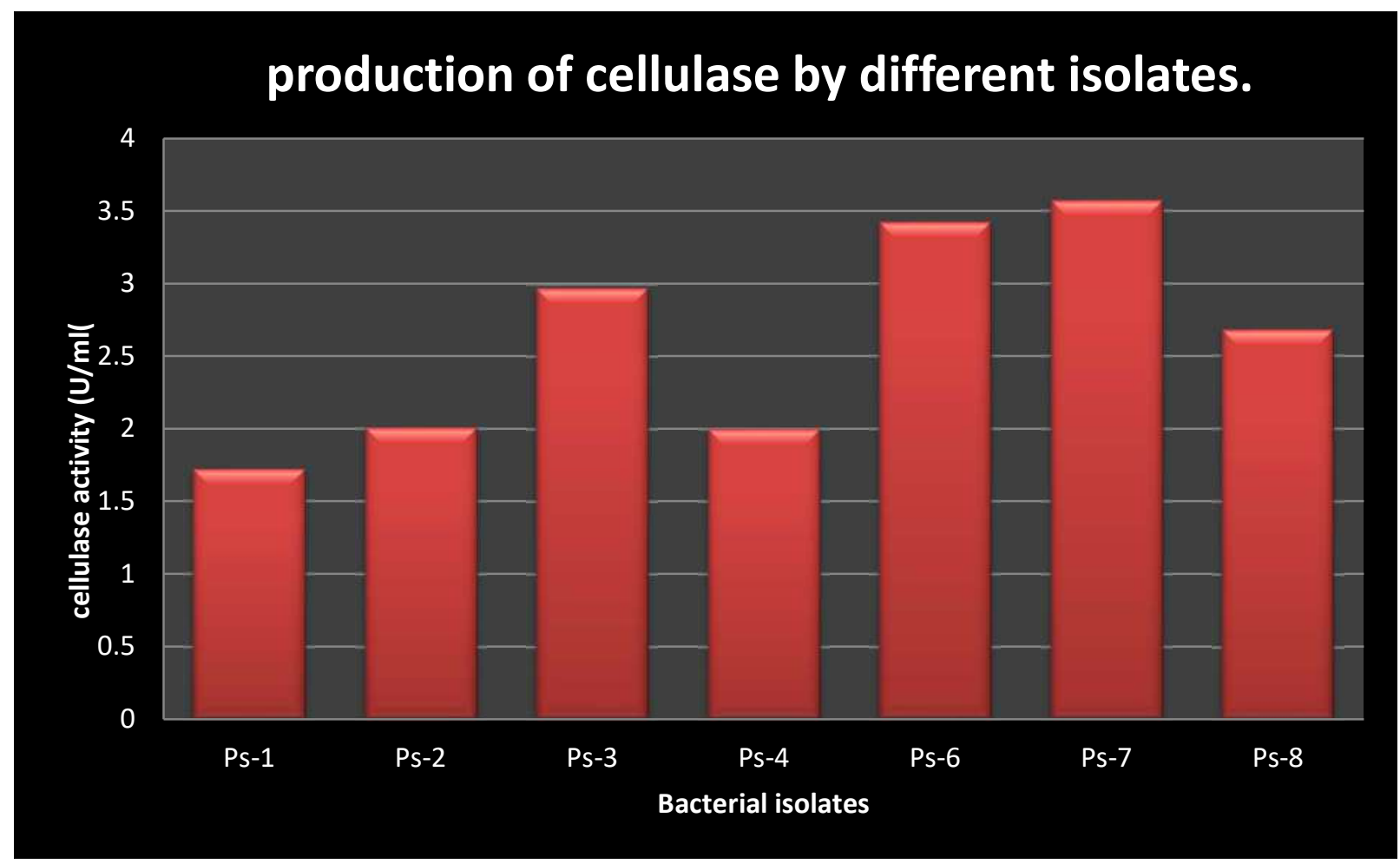

Graph 3.2 : Production of cellulase by different isolates. 
Towards Excellence: An Indexed, Refereed \& Peer Reviewed Journal of Higher Education / Ms. Hiral Shah, Ms. Ankita Patel, Ms. Rinku Valand, Ms. Payal Rathod \& Ms. Nidhi Gondaliya / Page $\underline{717-733}$

\subsection{Optimization of cellulase enzyme by SmF method}

\subsubsection{Optimization of temperature for cellulase production}

Optimization was carried out by incubating the fermentation flask at $28,37,48{ }^{\circ} \mathrm{C}$ and the cellulase activity were $1.002,3.568,2.448 \mathrm{U} / \mathrm{mL} / \mathrm{min}$, respectively. Thus, as show in graph 3.2 , maximum activity was observed at $37{ }^{\circ} \mathrm{C}=3.568$. the reduction of sugar conversion as well as enzyme production was observed at the temperature above $40{ }^{\circ} \mathrm{C}$. Ray, et. al., 2007 used saw dust for production of cellulase by Bacillus subtilis with cellulase activity obtained at $45{ }^{\circ} \mathrm{C}$. the CMAase activity declined when the initial $\mathrm{pH} 8$ for cellulolytic enzyme production by Paenibacillus sp (Yan-ling liang, 2014). In a previous study, P. curdlanolyticus B-6 was cultivated for enzyme production at $37{ }^{\circ} \mathrm{C}$. Furthermore, Kumar et al. reported that the optimal initial $\mathrm{pH}$ and temperature for CMCase production by $\mathrm{P}$. polymyxa was $37^{\circ} \mathrm{C}$.

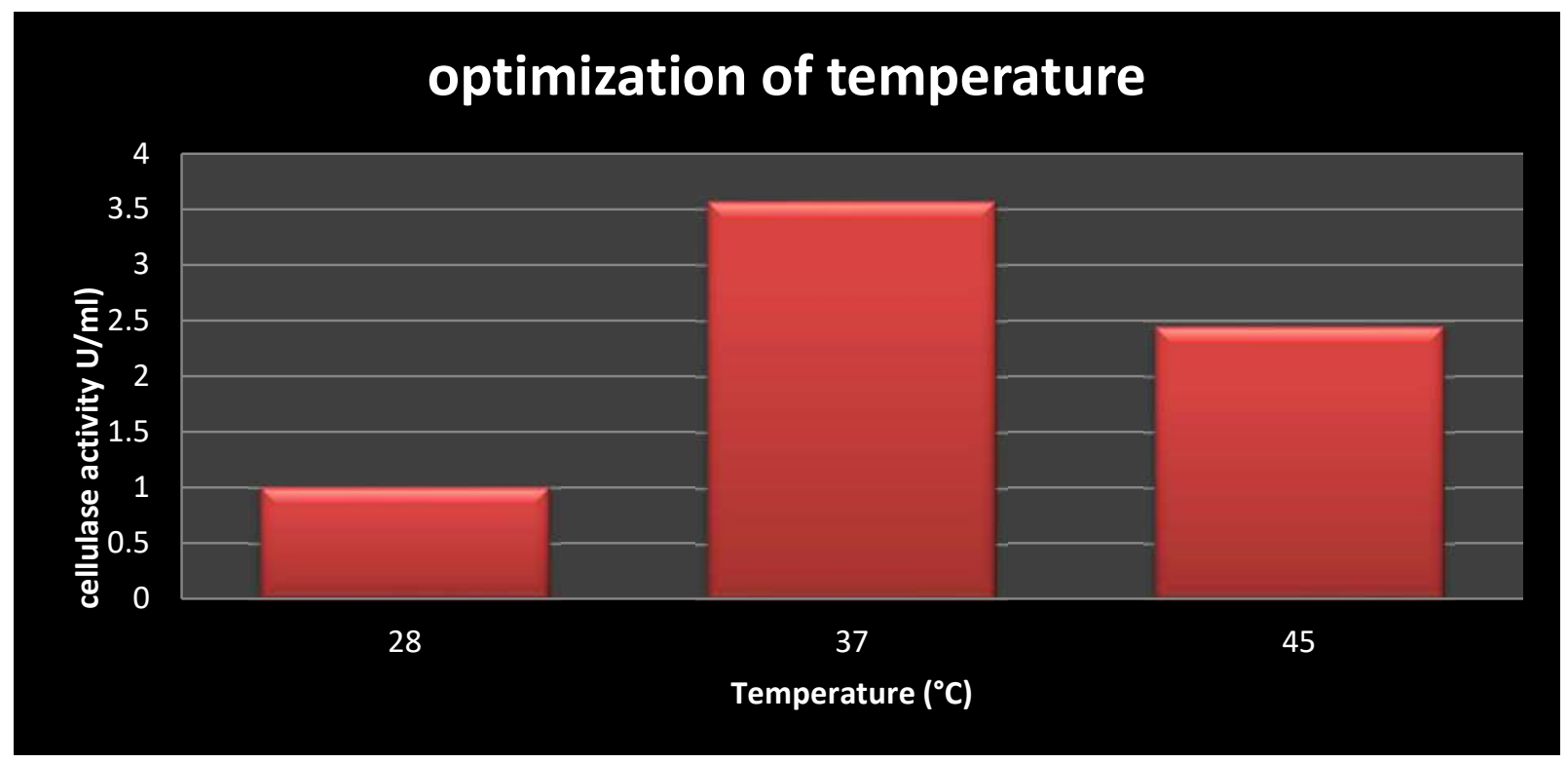

Graph 3.2 : Optimization of temperature for cellulase production by Bacillus pumillus.

\subsubsection{Optimization of $\mathrm{pH}$ for cellulase production}

As shown in graph 3.3, effect of $\mathrm{pH}$ on cellulase production was determined at $\mathrm{pH}$ values of 4, 5, 6,7 and 8 cellulase activity obtained were $3.179,2.435,2.370,2.809$ and $2.663 \mathrm{U} / \mathrm{mL} / \mathrm{min}$, respectively. Thus, as shown in graph 3.3, maximum activity was observed $\mathrm{pH} 4=3.179$.it was observed that the cellulase activity has a broad $\mathrm{pH}$ range between 3.0 and 9.0. Two major 
Towards Excellence: An Indexed, Refereed \& Peer Reviewed Journal of Higher Education / Ms. Hiral Shah, Ms. Ankita Patel, Ms. Rinku Valand, Ms. Payal Rathod \& Ms. Nidhi Gondaliya / Page

\section{$\underline{717-733}$}

activity peaks were obtained at $4.5 \mathrm{pH}$ and $7.5 \mathrm{pH}$ (Coa et al,. 2002) it was reported that the optimal pH for a cellulase from Bacillus subtilis was between 6.0 and 7.0 (Lee, et.al.,2010) and in another report the optimal $\mathrm{pH}$ activity of Bacillus subtilis cellulase was found to be between 4.0 and 4.5 (Mawadza, et. al.,1996)other report B.subtilis produce maximum cellulase activity was found to be at 7 . In a previous study, P. curdlanolyticus B-6 was cultivated for enzyme production at $\mathrm{pH} 7.0$. Furthermore, Kumar et al. reported that the optimal initial $\mathrm{pH}$ and temperature for CMCase production by P. polymyxa was 5.5, respectively. such different results may appear because of differences within the same genus.

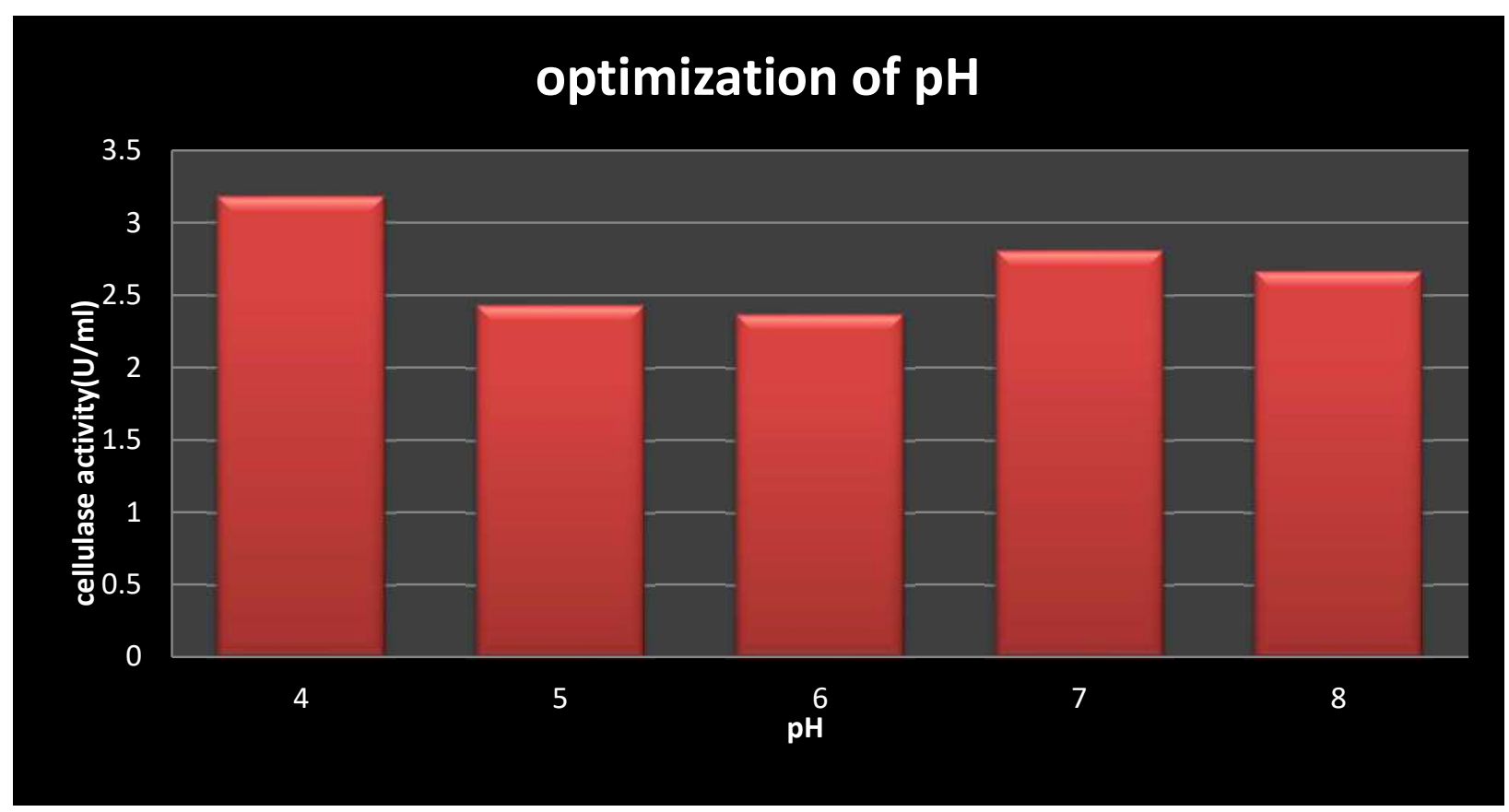

\subsubsection{Optimization of inoculums size for cellulase production}

As shown in graph 3.4, effect of inoculums size on cellulase production was determined at inoculums size of $0.5 \%, 1 \%, 1.5 \%, 2 \%, 2.5 \%$ cellulase activity obtained were $3.033,1.846,2.96$, 1.464, $1.761 \mathrm{U} / \mathrm{mL} / \mathrm{min}$, respectively. Thus, as shown in graph 5.4, maximum activity was observed inoculume size $0.5 \%=3.033$. The optimum formula of cellulase production from marine isolate Streptomyces ruber was $\mathrm{KH}_{2} \mathrm{PO}_{4} 1.5(\mathrm{~g} / \mathrm{L}), \mathrm{MgSO}_{4}$ 0.1(g/L), MnSO4 0.05(g/L), $\mathrm{NH}_{4} \mathrm{NO}_{3} 0.5(\mathrm{~g} / \mathrm{L}), \mathrm{NaCl} 1.5(\mathrm{~g} / \mathrm{L})$ with inoculum size of $0.5 \mathrm{ml}$ and in this study isolate Ps-7 have CMCase activity is 2.96 for inoculum size $1.5 \%$. (Shah et.al 2008) 


\section{optimization of inoculum size}

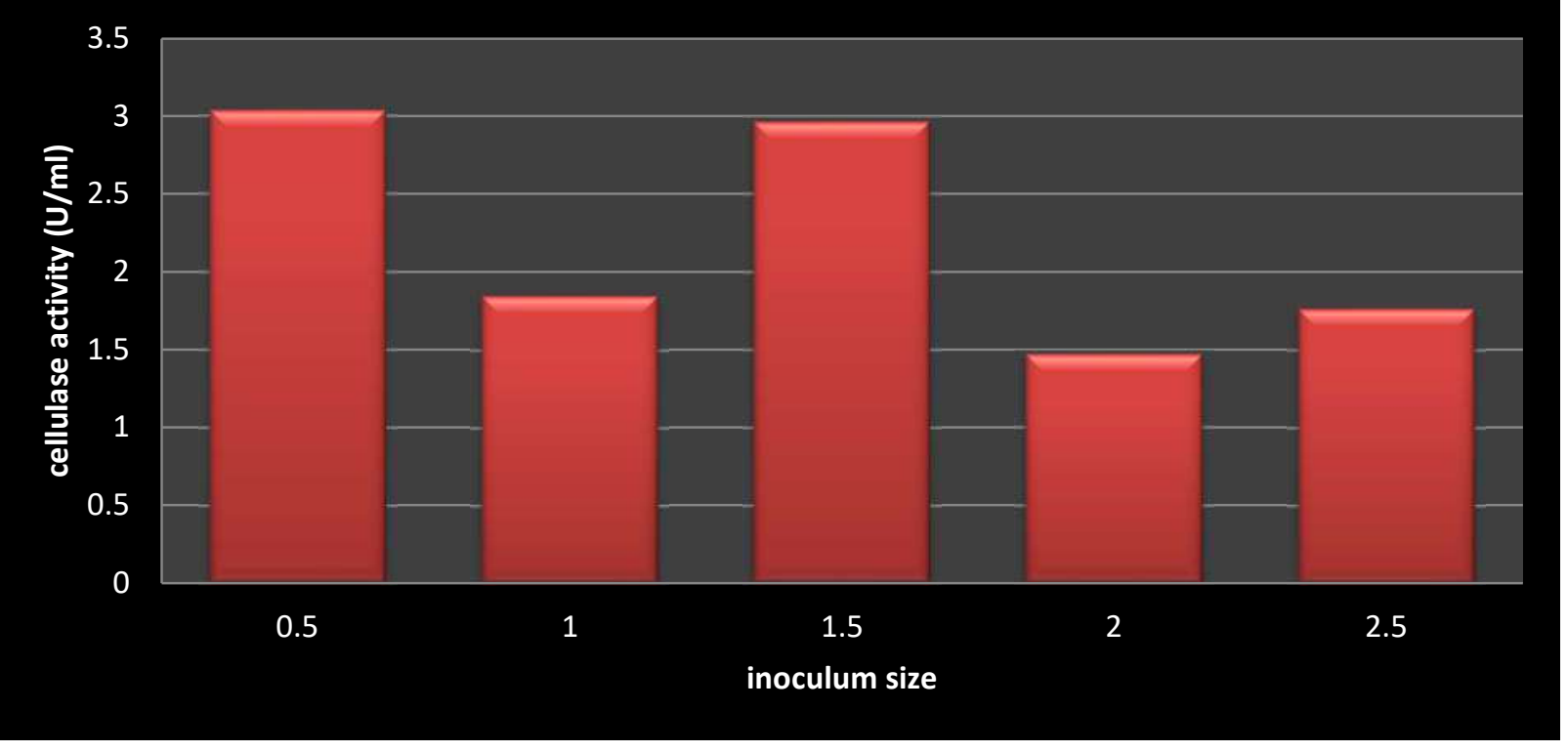

Graph : 3.4. Optimization of inoculum size for cellulase production by Bacillus pumillus

\section{Result and Conclusion}

To conclude the result obtained in this study clearly shows that certain bacterial isolates obtain from nearby zones and industrial areas have good capacity to produce cellulase in natural environmental conditions without adding any specific supplements and not even much modification in physical parameters are need. Result also clearly indicate Bacillus pumilus a Gram positive, rod shaped bacteria yields maximum cellulases activity. The optimum temperature and $\mathrm{pH}$ was determined at $37^{\circ} \mathrm{C}$ and $\mathrm{pH}$ 4. The maximum inoculum size was found using $0.5 \% \mathrm{v} / \mathrm{v}$ with highest production in medium by $\mathrm{SmF}$ method. There are main research work done such as Bacillus subtilis MTCC 441 \&Cellulomonas cellulans MTCC 23 are found potential for conversion of agro wastes for cellulase production by SSF method (Shah et.al 2008)

Our study aim fulfill today's need of potent strain of indigenous flora to remove agriculture and nonagricultural waste containing cellulosic materials. This study also conclude that every region 
Towards Excellence: An Indexed, Refereed \& Peer Reviewed Journal of Higher Education / Ms. Hiral Shah, Ms. Ankita Patel, Ms. Rinku Valand, Ms. Payal Rathod \& Ms. Nidhi Gondaliya / Page $\underline{717-733}$

has its one flora which can helpful to remove waste material and reduce pollution without any change of environmental conditions

\section{References}

1. Abou-Taleb, Khadiga AA, et al. (2009) "Nutritional and environmental factors affecting cellulase production by two strains of cellulolytic Bacilli." Australian Journal of Basic and Applied Sciences 3.3.

2. B. H. Lee, B. K. Kim, Y. J. Lee, C. H. Chung, and J. W. Lee,(2010), "Industrial scale of optimization for the production of carboxymethylcellulase from rice bran by a marine bacterium, Bacillus subtilis subsp. subtilis A-53," Enzyme and Microbial Technology,. 46,

3. C. Mawadza, F. C. Boogerd, R. Zvauya, and H. W. Van Verseveld,(1996) "Influence of environmental factors on endo- $\beta$-1,4-glucanase production by Bacillus HR68, isolated from a Zimbabwean hot spring," Antonie van Leeuwenhoek, 69

4. Cao, Y. and Huimin, T. (2002). "Effects of cellulase on the modification of cellulose." Carbohydrate Reserarch. 337:

5. Fatemeh Azadian, Arastoo Badoei-dalfard, Abdolhamid Namaki-Shoushtari, Zahra Karami, Mehdi Hassanshahian, (2017) " Production and characterization of an acidothermophilic, organic solvent stable cellulase from Bacillus sonorensis HSC7 by conversion of lignocellulosic wastes," Journal of Genetic Engineering and Biotechnology, Volume 15(1)

6. Gao,W.(2012), "Enhanced Carboxymethylcellulase production by a newly isolated marine bacterium,Cellulophaga lytica LBH-14”,Using Rice Bran.Jr of Microbiology and Biotechnology,22(10)

7. Goyal, Varsha, et al.(2014) "Parametric optimization of cultural conditions for carboxymethyl cellulase production using pretreated rice straw by Bacillus sp. 313SI under stationary and shaking conditions." Biotechnology research international 2014. 
8. Immanuel, G., et al. (2006) "Effect of different growth parameters on endoglucanase enzyme activity by bacteria isolated from coir retting effluents of estuarine environment." International Journal of Environmental Science \& Technology 3.1.

9. Kanafusa-Shinkai, S., Wakayama, J. I., Tsukamoto, K., Hayashi, N., Miyazaki, Y., Ohmori, H.\& Yokoyama, H. (2013). “ Degradation of microcrystalline cellulose and non-pretreated plant biomass by a cell-free extracellular cellulase/hemicellulase system from the extreme thermophilic bacterium Caldicellulosiruptor bescii." Journal of bioscience and bioengineering, 115(1), 64-70.

10. Liang, Y. L., Zhang, Z., Wu, M., Wu, Y., \& Feng, J. X. (2014). "Isolation, screening, and identification of cellulolytic bacteria from natural reserves in the subtropical region of China and optimization of cellulase production by Paenibacillus terrae ME27-1." BioMed research international, 2014.

11. Miller, G. L. (1959). "Use of dinitrosalicylic acid reagent for determination of reducing sugar". Analytical chemistry, 31(3),

12. Neelamegam Annamalai, Mayavan Veeramuthu Rajeswari, Thangavel Balasubramanian, (2014), "Enzymatic saccharification of pretreated rice straw by cellulase produced from Bacillus carboniphilus CAS 3 utilizing lignocellulosic wastes through statistical optimization,BiomassandBioenergy", Volume68

13. Ramesh Chander Kuhad, Deepa Deswal, Sonia Sharma, Abhishek Bhattacharya, Kavish Kumar Jain, Amandeep Kaur, Brett I. Pletschke, Ajay Singh, Matti Karp, (2016) "Revisiting cellulase production and redefining current strategies based on major challenges," Renewable and Sustainable Energy Reviews, Volume 55.

14. Ray, A. K., Bairagi, A., Ghosh, K. S., \& Sen, S. K. (2007). "Optimization of fermentation conditions for cellulase production by Bacillus subtilis CY5 and Bacillus circulans TP3 isolated from fish gut. Acta Ichthyologica et Piscatoria," 1(37).

15. Sadhu, Sangrila, and Tushar Kanti Maiti. (2013): "Cellulase production by bacteria: a review." Microbiology Research Journal International .

16. Sethi, S., Datta, A., Gupta, B. L., \& Gupta, S. (2013). "Optimization of cellulase production from bacteria isolated from soil". ISRN biotechnology, 
Towards Excellence: An Indexed, Refereed \& Peer Reviewed Journal of Higher Education / Ms. Hiral Shah, Ms. Ankita Patel, Ms. Rinku Valand, Ms. Payal Rathod \& Ms. Nidhi Gondaliya / Page

$\underline{717-733}$

17. Shah, H.R., Pathak, J.P., and Parikh, S.C,(2008) "Bioconversion of agrowaste into cellulase using solid state fermentation by mixer of Bacillus subtilis MTCC 441 \&Cellulomonascellulans MTCC 23" pub in GEOBIOS. 35

18. Shaikh, Nilofer M., et al. (2013). "Isolation and Screening of Cellulolytic Bacteria Inhabiting Different Environment and Optimization of Cellulase Production." Universal Journal of Environmental Research \& Technology 3.1

19. Singhania, R. R., Sukumaran, R. K., Patel, A. K., Larroche, C., \& Pandey, A. (2010). Advancement and comparative profiles in the production technologies using solid-state and submerged fermentation for microbial cellulases. Enzyme Microbial Technology, 46:541-549.

20. Singhania, R. R., Sukumaran, R. K., Rajasree, K. P., Mathew, A., Gottumukkala, L., \& Pandey, A. (2011). Properties of a major P-glucosidase-BGLl from Aspergillus niger . Enzyme Microbial Technology,46.

21. Yang, Weiping, et al. (2014): "Isolation and identification of a cellulolytic bacterium from the Tibetan pig's intestine and investigation of its cellulase production." Electronic Journal of Biotechnology 17.6

\author{
Hiral Shah \\ Assistant professor \\ Annaya Institute of Science \\ \& \\ Ankita Patel \\ Assistant Professor \\ Department of forensic Science and biochemistry \\ Gujarat University \\ \& \\ Corresponding Author \\ Rinku Valand, Payal Rathod \& Nidhi Gondaliya \\ Assistant professor \\ Department of Life science \\ Gujarat University, Gujarat, India \\ nidhi.gondaliya@gujaratuniversity.ac.in \\ nidhi1385gondaliya@gmail.com
}

